\title{
Antimicrobial Activity of Selected Essential Oils against Bacteria Isolated from Freshwater Fish
}

\author{
Miroslava Kačániová ${ }^{1,2}$, Alīna Klūga ${ }^{3}$, Margarita Terentjeva ${ }^{3}$, Simona Kunová4, \\ Katarína Rovná ${ }^{1}$, Jana Žiarovská ${ }^{5}$, Petra Borotová ${ }^{6}$, Veronika Válková ${ }^{1,6}$, Lucia Gálovičová ${ }^{1}$ \\ ${ }^{1}$ Slovak University of Agriculture, Faculty of Horticulture and Landscape Engineering, Nitra 949 76, Tr. A. \\ Hlinku 2, Slovakia \\ ${ }^{2}$ University of Rzeszow, Institute of Food Technology and Nutrition, 35-601 Rzeszow, Cwiklinskiej 1, \\ Poland \\ ${ }^{3}$ Latvia University of Life Sciences and Technologies, Faculty of Veterinary Medicine, K. Helmana iela 8, \\ LV-3004, Jelgava, Latvia \\ ${ }^{4}$ Slovak University of Agriculture, Faculty of Biotechnology and Food Sciences, Nitra 949 76, Tr. A. Hlinku \\ 2, Slovakia \\ ${ }^{5}$ Slovak University of Agriculture, Faculty of Agrobiology and Food resources, Nitra 949 76, Tr. A. Hlinku 2, \\ Slovakia \\ ${ }^{6}$ Slovak University of Agriculture, AgroBioTech Research Centre, Tr. A. Hlinku 2, 94976 Nitra, Slovakia
}

\begin{abstract}
The aim of study was to determine the antimicrobial activity of ten essential oils against ten microorganisms isolated from fish. The following essential oils were tested: Cymbopogon nardus Rendle, Citrus limon, Leptospermum petersonii Bailey, Gaultheria procumbens, Pelargonium graveolens, Citrus paradisi, Citrus aurantifolia, Litsea cubeba Pers., Citrus reticulata Blanko, Vetiveria zizanoides. The disc diffusion method and microdilution method were used for determination of antimicrobial activity. Rhodotorula spp., Aerococcus spp., Aerococcus viridans, Enterococcus faecium, Enterococcus moraviensis, Aeromonas spp., Delftia acidovorans, Pseudomonas gessardii, Yersinia spp., Yersinia ruckeri, Yersinia enterocolitica were tested in the present study. The best antimicrobial activity of Leptospermum petersonii Bailey were found against Aerococcus spp., Enterococcus faecium, E. moraviensis, Delftia acidovorans, Pseudomonas gessardii, Yersinia ruckeri and Y. enterocolitica. Litsea cubeba Pers. was effective against Delftia acidovorans, Yersinia enterocolitica, Enterococcus faecium using the disc diffusion method. The best minimal inhibition concentration (MIC $50-1.5 \mu \mathrm{L} / \mathrm{mL}$ resp. MIC $90-1.6 \mu \mathrm{L} / \mathrm{mL}$ ) was found for Litsea cubeba Pers. against Aerococcus spp. and Yersinia spp. using microdilution method.
\end{abstract}

Keywords: essential oils, yeast, Gram-positive bacteria, Gram-negative bacteria, disc diffusion method, microdilution method

\section{Introduction}

Essential oils are multicomponent, hydrophobic plant extracts widely applied in medicine. Their antimicrobial activity has been known for a long time. They are produced from plants by only

\footnotetext{
* Corresponding author: Miroslava Kačániová, miroslava.kacaniova@gmail.com

(cc) EY-NC-ND @ 2021 M. Kačániová et al., published by De Gruyter Open. This work was licensed under the Creative Commons Attribution-NonCommercialNoDerivs 3.0 License
}

physical means - distillation or pressing from the whole plant or from a specific part of the plant [1]. Essential oils are generally extracted by highpressure or low-pressure distillation. Other extraction methods include solvent extraction, absolute extraction of essential oil, cold pressing, extraction with liquid carbon dioxide or the use of microwaves [2].

Citronella oil (Cymbopogon nardus aetheroleum) is an essential oil known for its natural insect 
repellent ability and it is important for the perfume and pharmaceutical industries [3]. The most common applications are antipyretic, diuretic, treatment of mental illnesses, perfume ingredient or as a component of aromatic tea [4].

Lemon silica (Limonis aetheroleum) is a hydrophobic substance extracted from lemon peel, which is used as a flavoring in soft drinks and in some foods [5].

Plants referred to as "tea trees" belong to a group of unrelated plant species, including Camellia sinensis, Kunzea ericoides, Leptospermum scoparium and Leptospermum petersonii. Some of these species have been used by Australian aborigines and early European settlers for a variety of infectious diseases, including urinary tract infections, intestinal problems, coughs, colds, burns, gum disease [6]. Gaulter oil is extracted from the leaves of the plant Gaultheria (family Ericaceae). The main chemical components of this essential oil are phenols (99\% methyl salicylate and gaultherin), tannin and resin. It has anti-inflammatory and antiseptic effects [7].

Pelargonium graveolens is an aromatic shrub. This essential oil is widely used in the perfumery and cosmetics industry [8].

Grapefruit oil has insecticidal and antimicrobial effects [9]. Grapefruit essential oil is obtained from the bark of grapefruit. Its main components are terpenes and oxides of terpenes - alcohols, ethers, aldehydes, ketones and esters [10].

Lime oil (Citri aurantifoliae aetheroleum) is one of the most widely used essential oils in the food, pharmaceutical and cosmetic industry. It is commonly added to beverages, bakery products and perfumes [11].

Litsea cubeba silica (Litseae cubebae aetheroleum) is widely used as a botanical insecticide, an ingredient in spices, in cosmetics and traditional Chinese medicine [12].

Mandarin green oil (Citri reticulatae aetheroleum) is used mainly in the perfumery and food industry because of its aroma. The production of this essential oil begins in September when the fruits are still unripe [13].

Vetiver oil (Oleum vetiveriae) has therapeutic, hepatoprotective, antihyperglycemic, antiseptic and antioxidant properties [14].

Bacterial pathogens associated with fish are indigenous and non-indigenous. The nonindigenous contaminants of fish or the habitat include Escherichia coli, Clostridium botulinum, Shigella dysenteriae, Staphylococcus aureus, Listeria monocytogenes and Salmonella. The indigenous bacterial pathogens are found naturally living in the fish's habitat for example Vibrio species and Aeromonas species. The bacteria from fish only cause infection when fish are physiologically unbalanced, nutritionally deficient, or there are other stressors, i.e., poor water quality, overstocking, which allow opportunistic bacterial infections to prevail.

The aim of the study was to determine the antimicrobial activity of essential oils against bacteria isolated from fish using the disc diffusion and the microdilution method. Antimicrobial activity of EO has shown in the present study reveal the possible application of those in prevention and treatment of common bacterial pathogens in freshwater fish.

\section{Material and Methods}

Altogether 10 essential oils (Hanus a.s., Nitra, Slovakia) were used in the present study: Cymbopogon nardus Rendle, Citrus limon, Leptospermum petersonii Bailey, Gaultheria procumbens, Pelargonium graveolens, Citrus paradisi, Citrus aurantifolia, Litsea cubeba Pers., Citrus reticulata Blanko, Vetiveria zizanoides were tested.

\section{Microorganisms tested}

Fish isolates were originated from wild and aquacultured roach (Rutilus rutilus) and bream (Abramis brama) from skin, gills and gut samples. Rhodotorula spp., Aerococcus spp., Aerococcus viridans, Enterococcus faecium, Enterococcus moraviensis, Aeromonas spp., Delftia acidovorans, Pseudomonas gessardii, Yersinia spp., Yersinia ruckeri, Yersinia enterocolitica were isolated from fish and identified with MALDI-TOF MS Biotyper.

\section{Antimicrobial activity}

Antibacterial activity was examined by agar disc diffusion and microdilution method [16]. In our study, ticarcillin was used as positive control.

\section{Results and Discussion}

Comparing the values obtained and evaluating the results, we can conclude that the largest inhibition zone was reached by Leptospermum petersonii with an inhibition zone diameter of $34.00 \mathrm{~mm}$ against Delftia acidovorans (Figures 1-11). The best antimicrobial activity against Rhodotorula spp. was found with $L$. cubeba $(15.67 \mathrm{~mm})$ and $P$. graveolans EO $(10.67 \mathrm{~mm})$. The weak antibacterial activity showed $C$. reticulata, $C$. paradisi and $C$. nardus $(3.33 \mathrm{~mm})$ against Rhodotorula spp. (Figure 1). L. petersonii (25 mm) and L. cubeba $(20.33 \mathrm{~mm})$ showed the best antimicrobial activity against Aerococcus spp. (Figure 2). Similar results were found against $A$. viridans where L. cubeba $(21.33 \mathrm{~mm})$ showed the best antimicrobial effect (Figure 3 ). The best antimicrobial activity against E. faecium (Figure 4) 
was found with L. Cubeba EO (27 mm). Similar results showed $L$. cubeba (Figure 5 ) against $E$. moravensis $(30.33 \mathrm{~mm}$ ). Aeromonas spp. (Figure 6 ) was the most sensitive against $V$. zizanoides $(21.33 \mathrm{~mm})$. The best antimicrobial activity of $L$. petersonii (Figure 7) was found against $D$. acidovorans (34 mm). P. gesessardii (Figure 8) was the most sensitive against $L$. petersonii (17 $\mathrm{mm}$ ). L. cubeba (Figure 9) showed the best antimicrobial activity against Yersinia spp. (31 $\mathrm{mm}$ ) and $L$. petersonii (Figure 10-11) showed the best antimicrobial activity against $Y$. enterocolitica $(26.33 \mathrm{~mm})$ and $Y$. ruckeri (19.67 $\mathrm{mm})$.

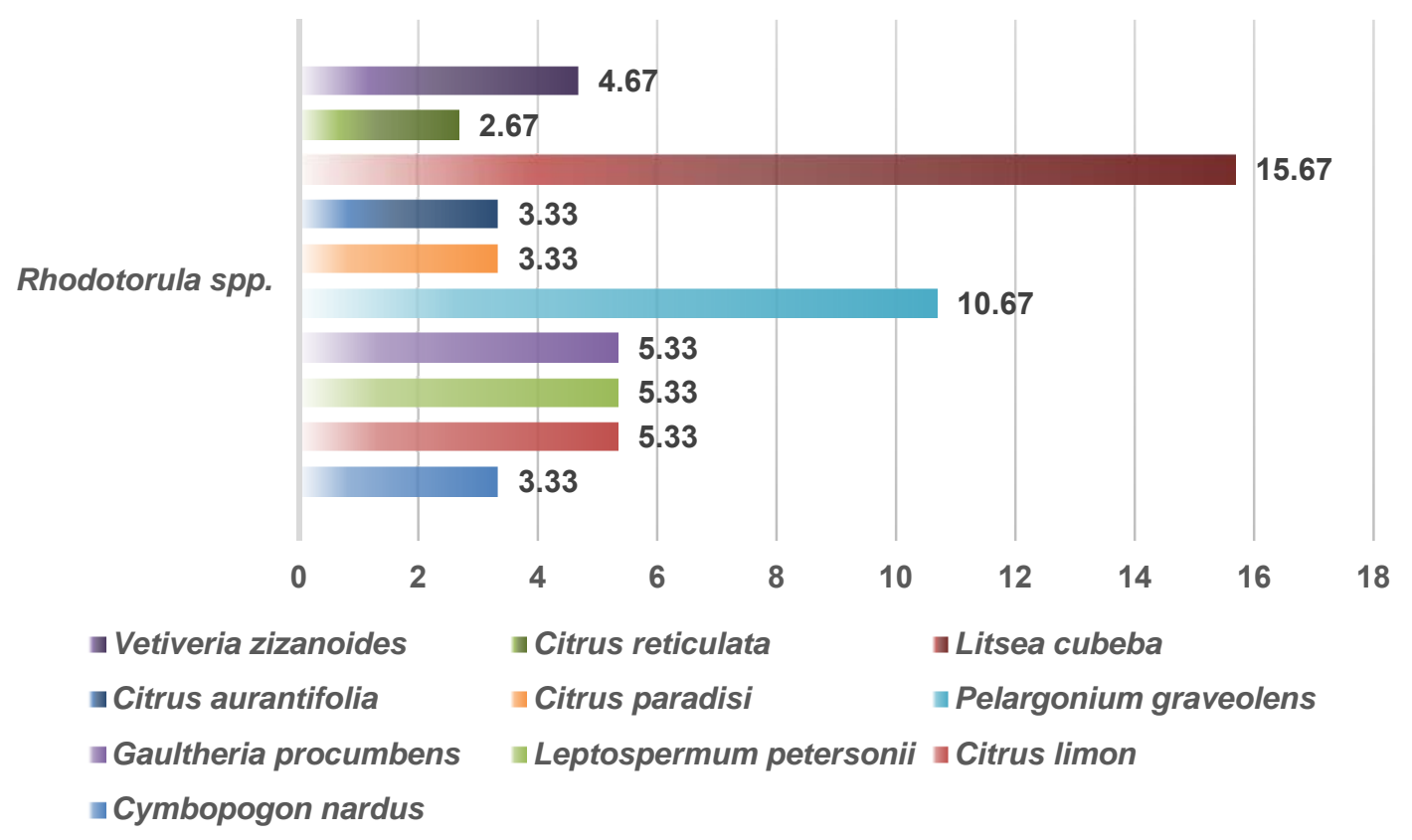

Figure 1. Antimicrobial activity of EOs against Rhodotorula spp. in mm

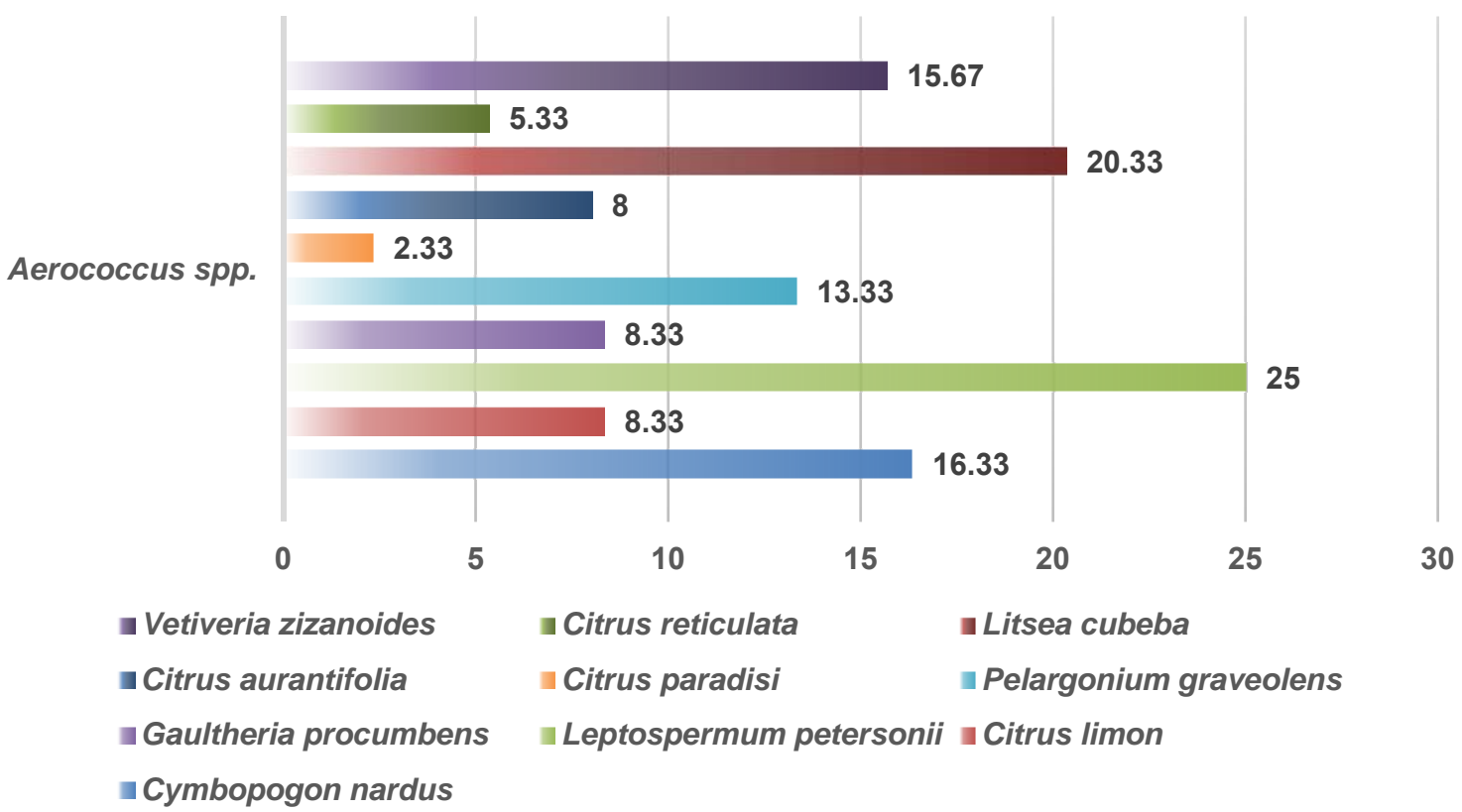

Figure 2. Antimicrobial activity of EOs against Aerococcus spp. in $\mathrm{mm}$ 


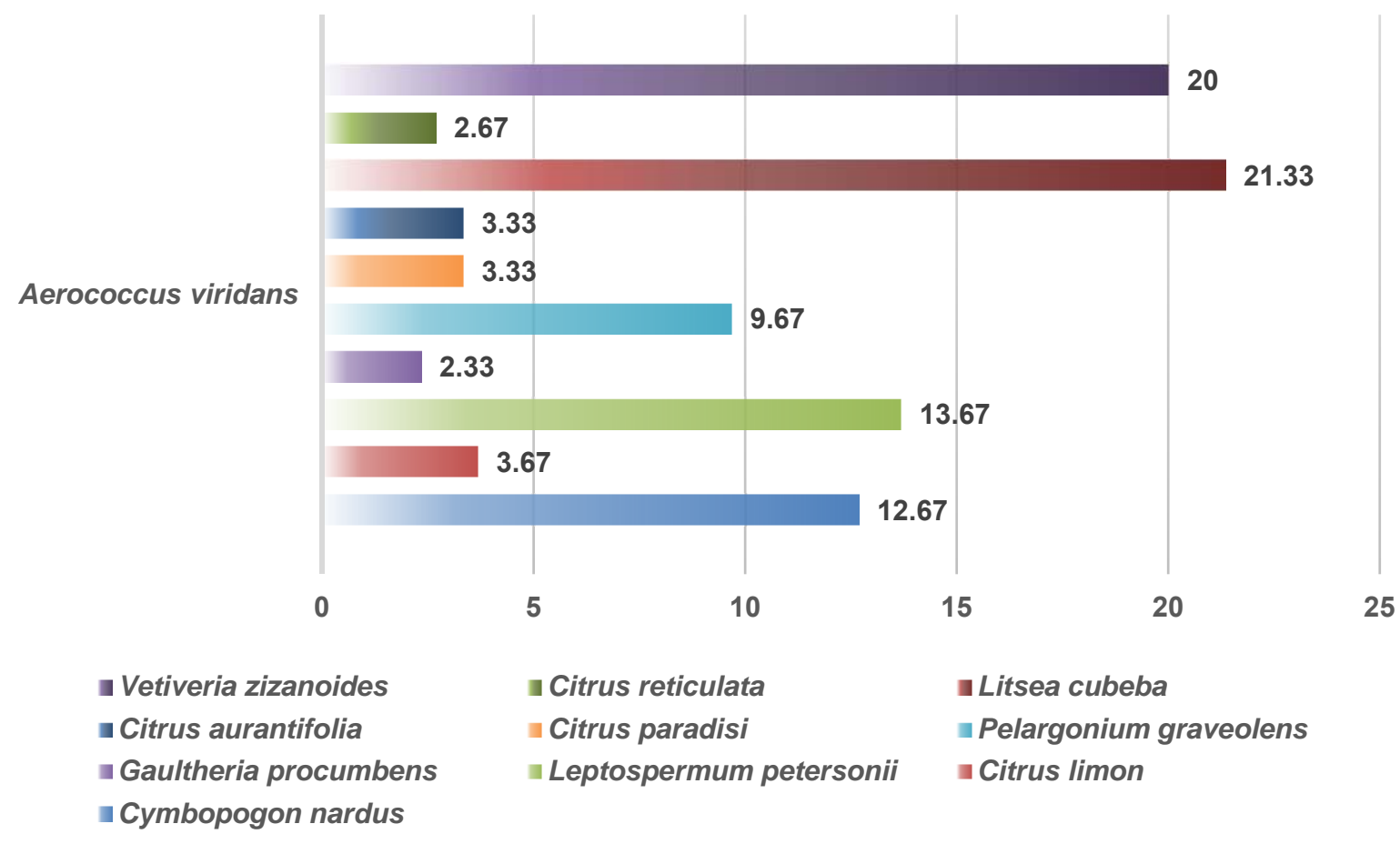

Figure 3. Antimicrobial activity of EOs against Aerococcus viridans in $\mathrm{mm}$

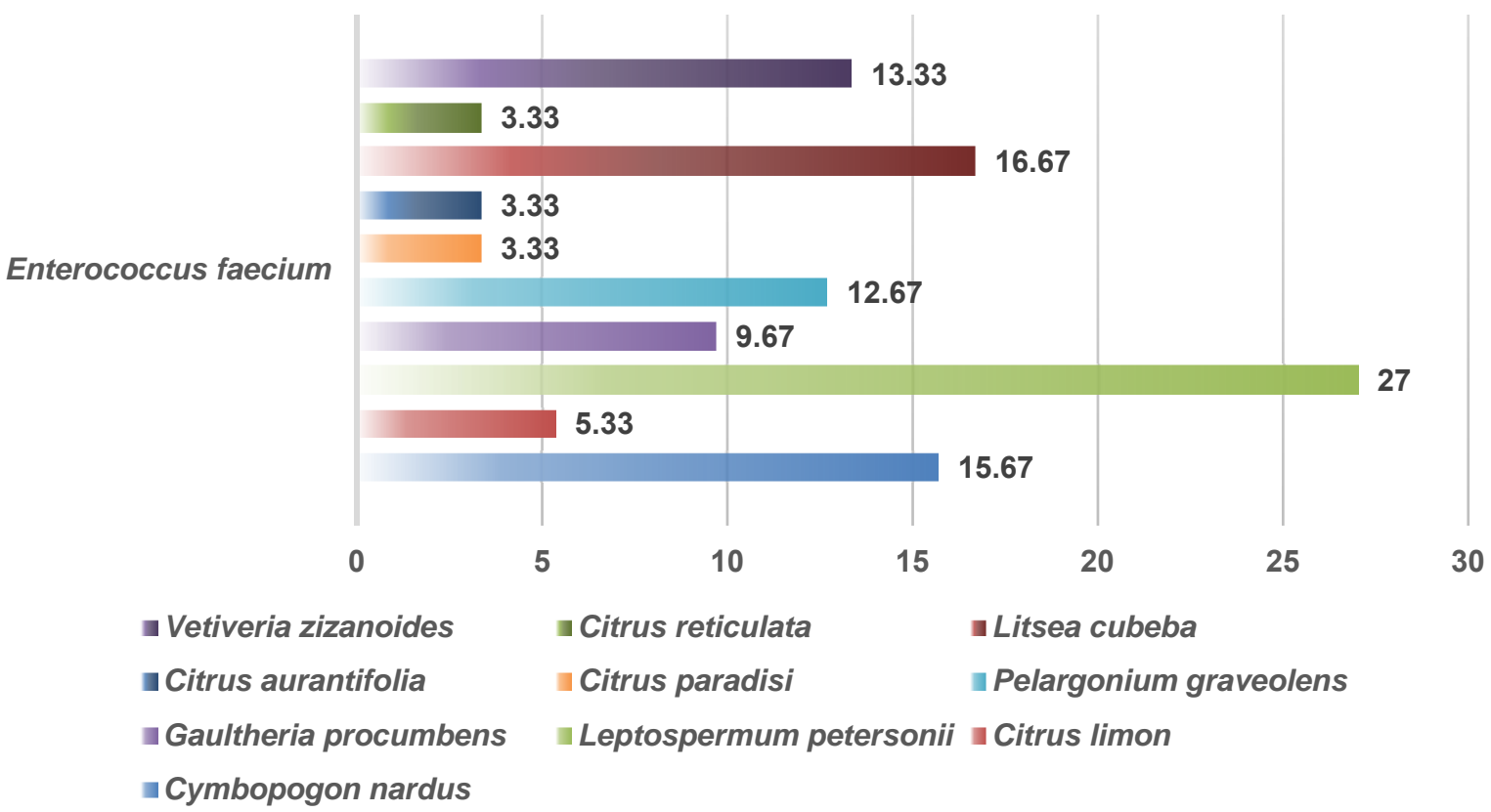

Figure 4. Antimicrobial activity of EOs against Enterococcus faecium in $\mathrm{mm}$ 


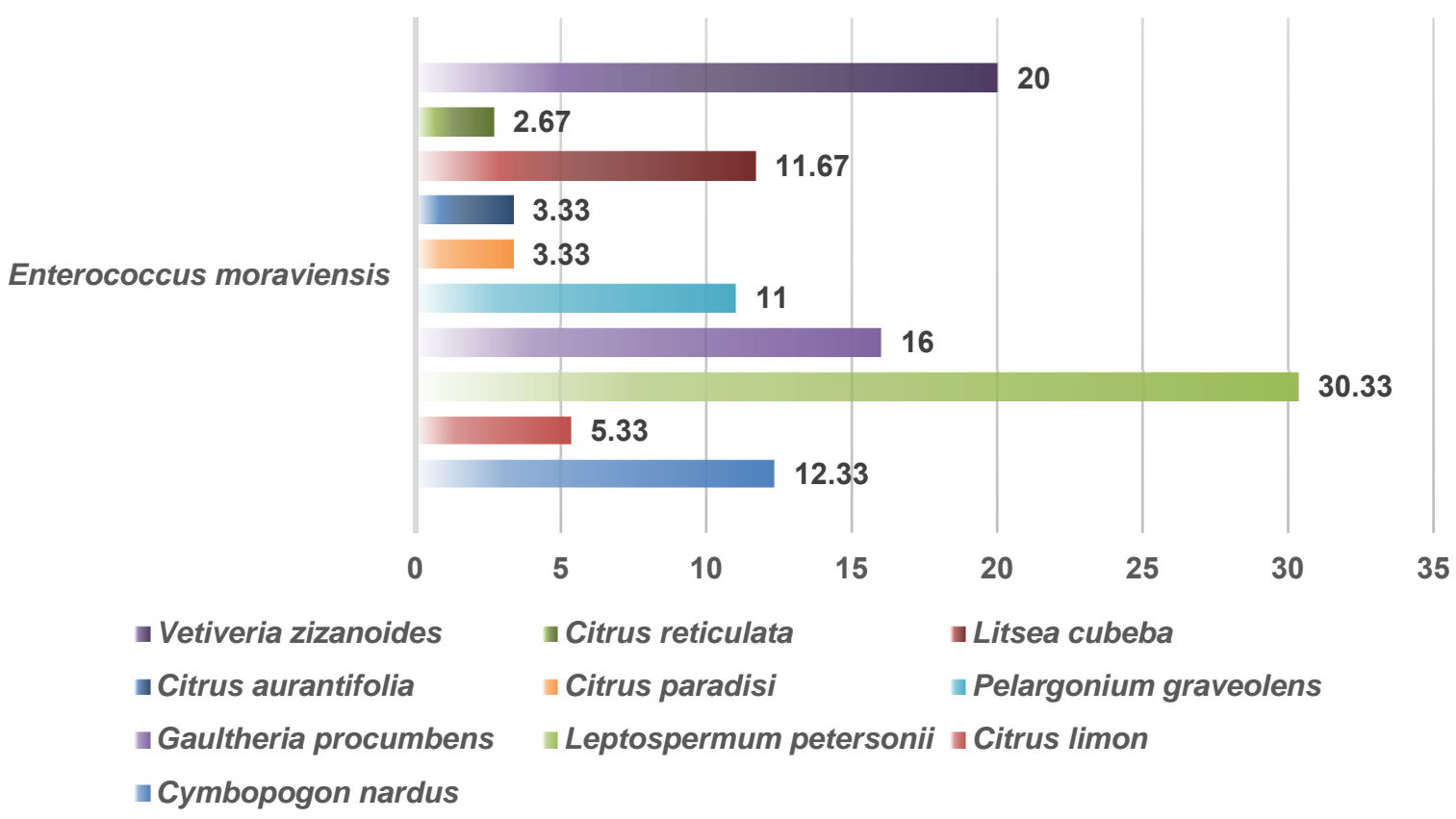

Figure 5. Antimicrobial activity of EOs against Enterococcus moraviensis in $\mathrm{mm}$

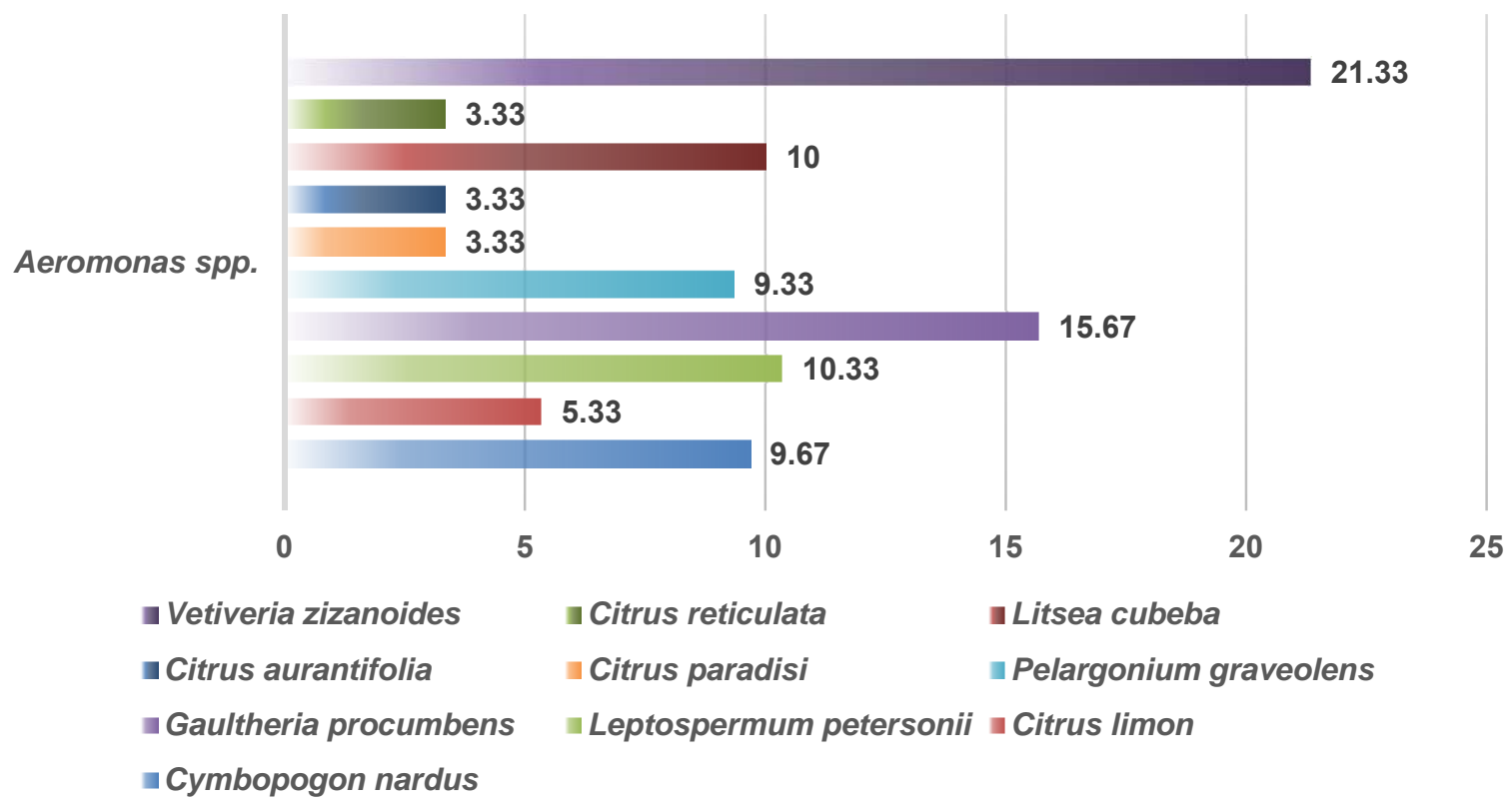

Figure 6. Antimicrobial activity of EOs against Aeromonas spp. in mm 


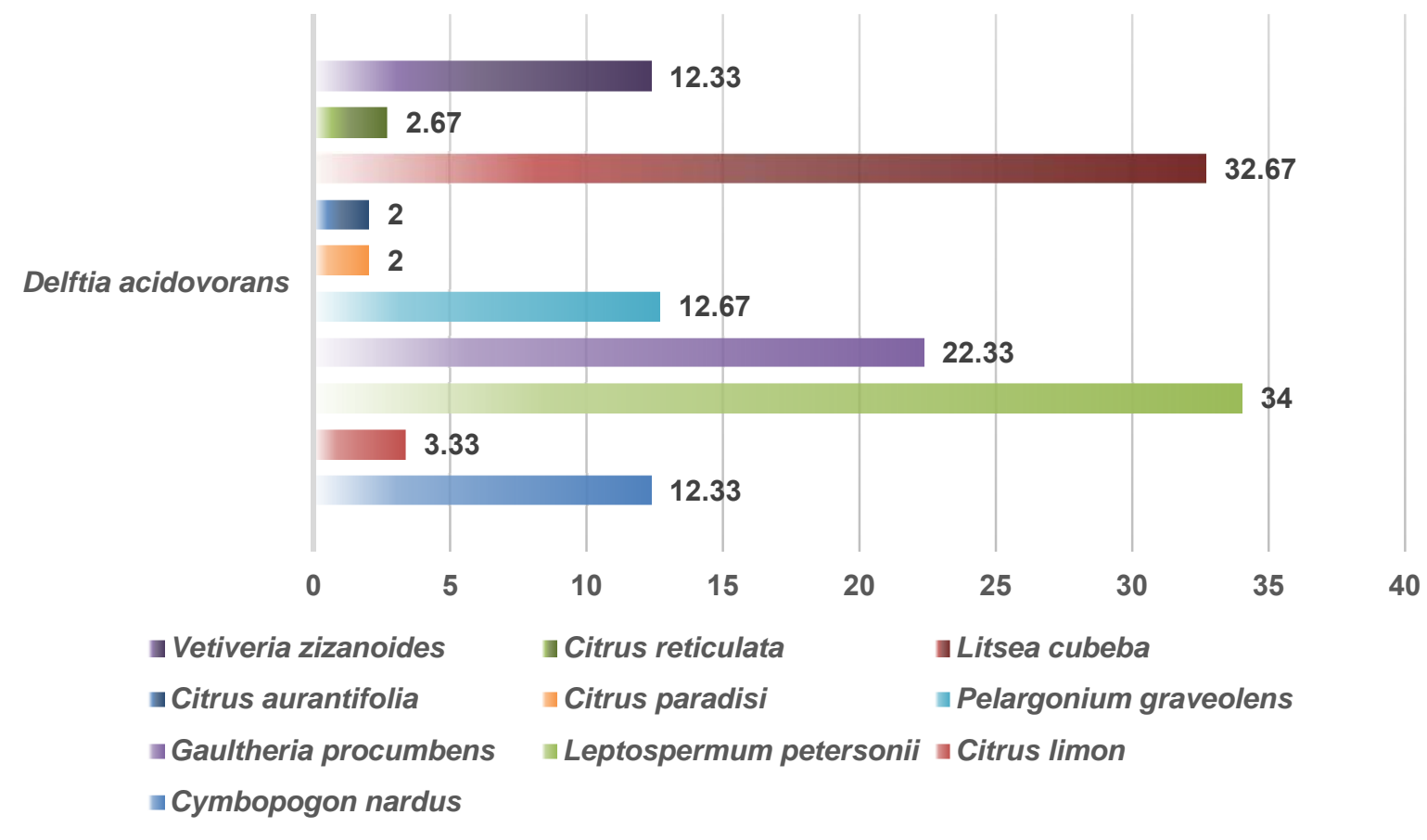

Figure 7. Antimicrobial activity of EOs against Delftia acidovorans in $\mathrm{mm}$

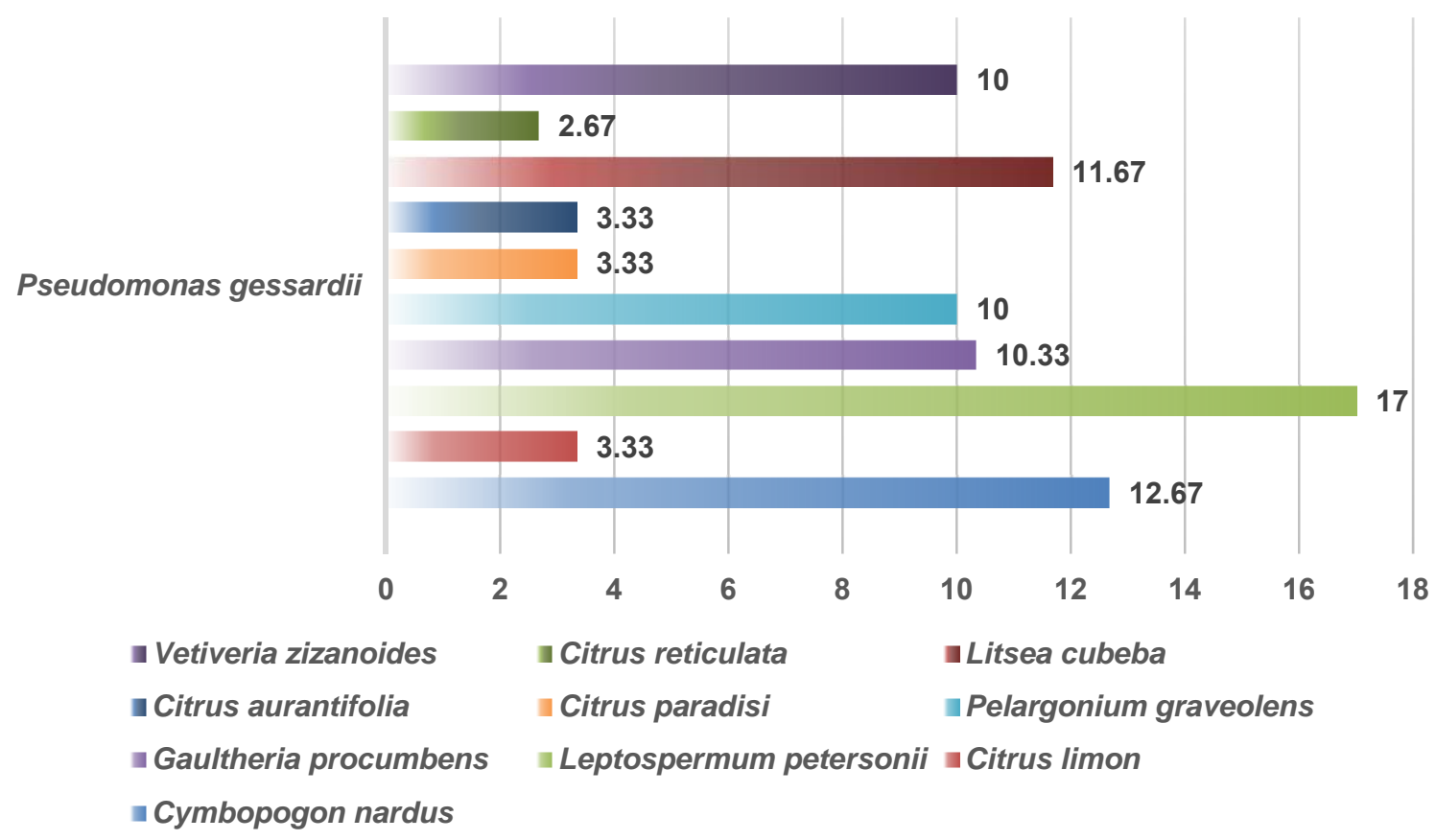

Figure 8. Antimicrobial activity of EOs against Pseudomonas gessardii in $\mathbf{m m}$ 


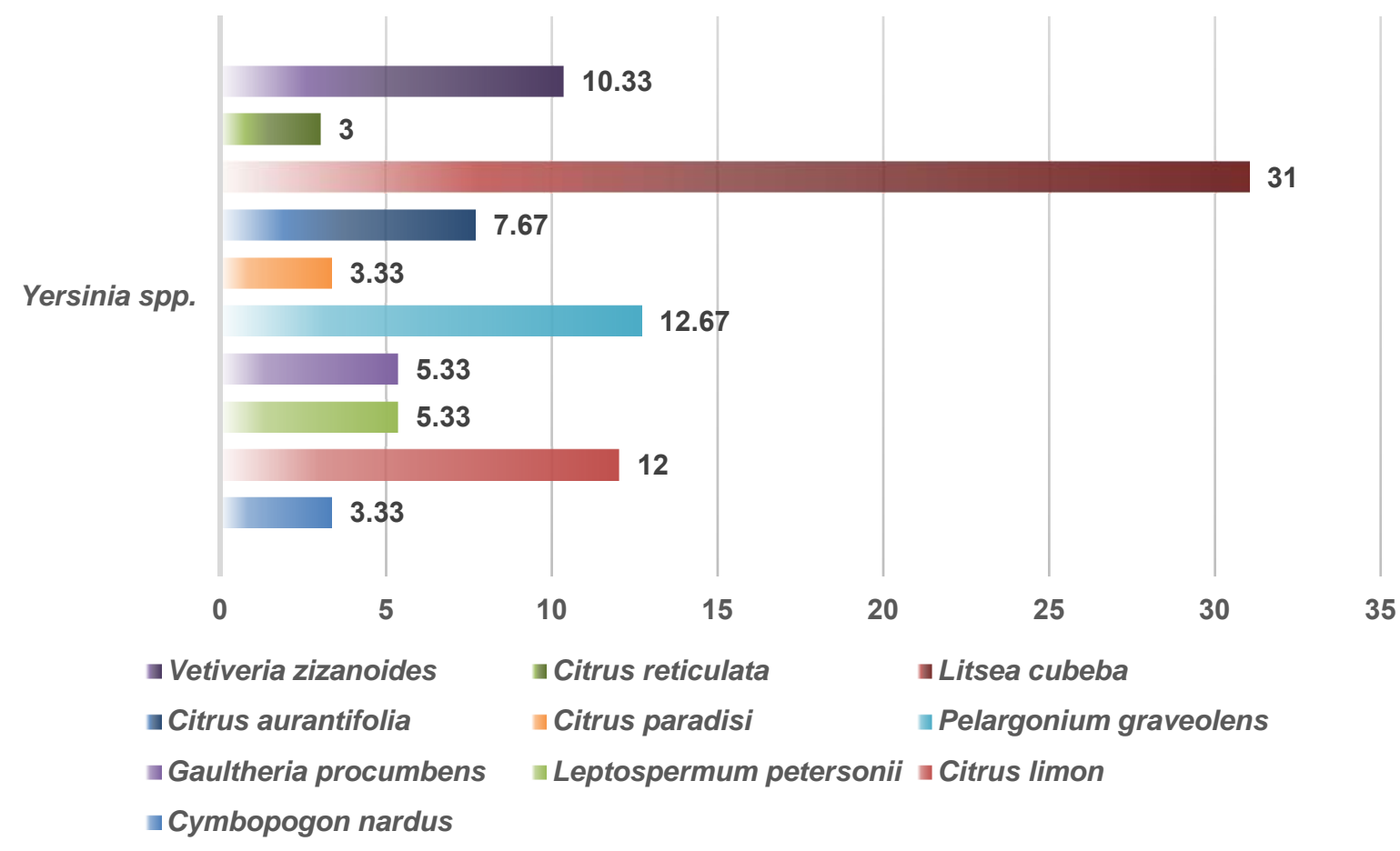

Figure 9. Antimicrobial activity of EOs against Yersinia spp. in $\mathrm{mm}$

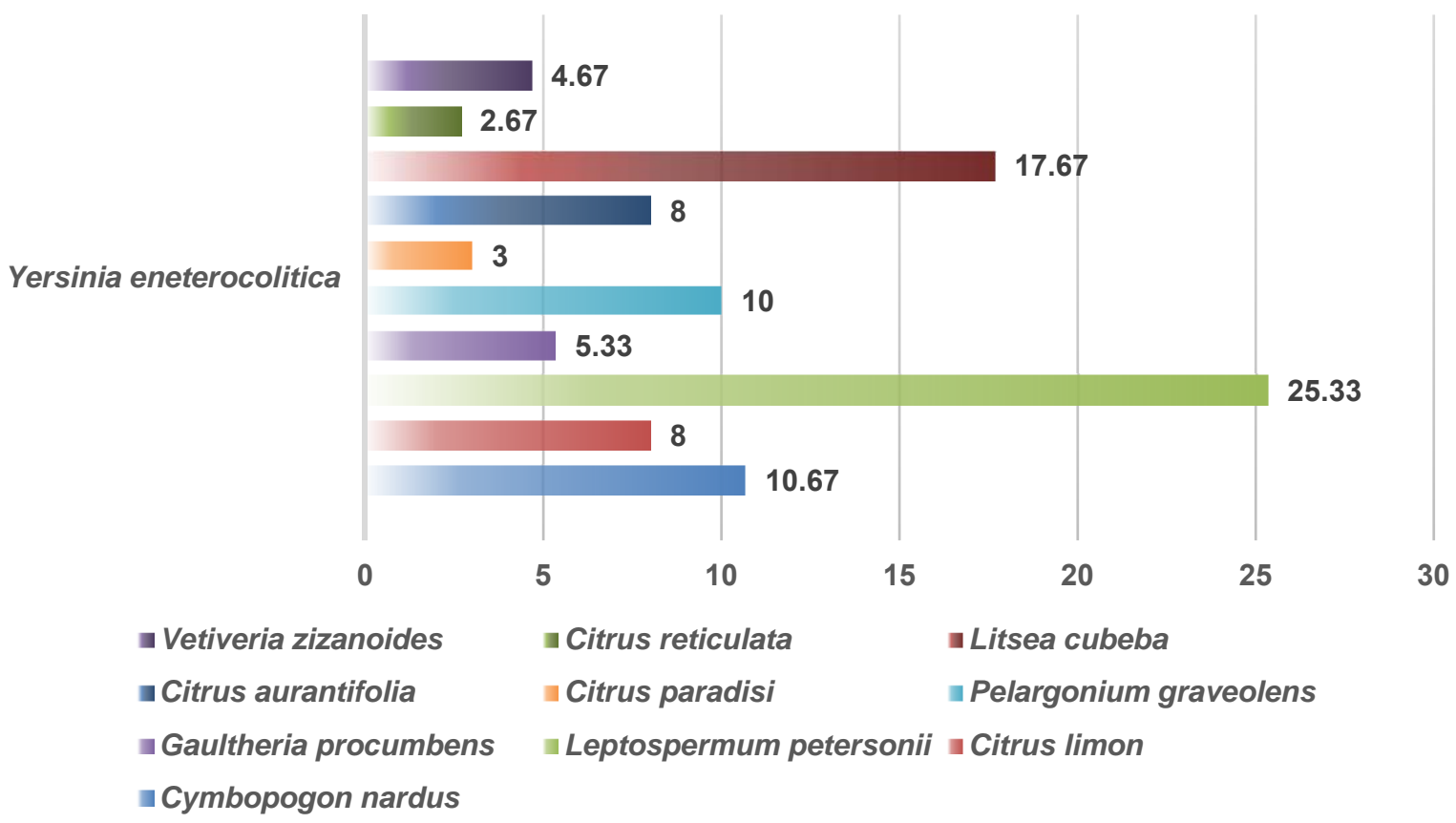

Figure 10. Antimicrobial activity of EOs against Yersinia enterocolitica in $\mathbf{m m}$ 


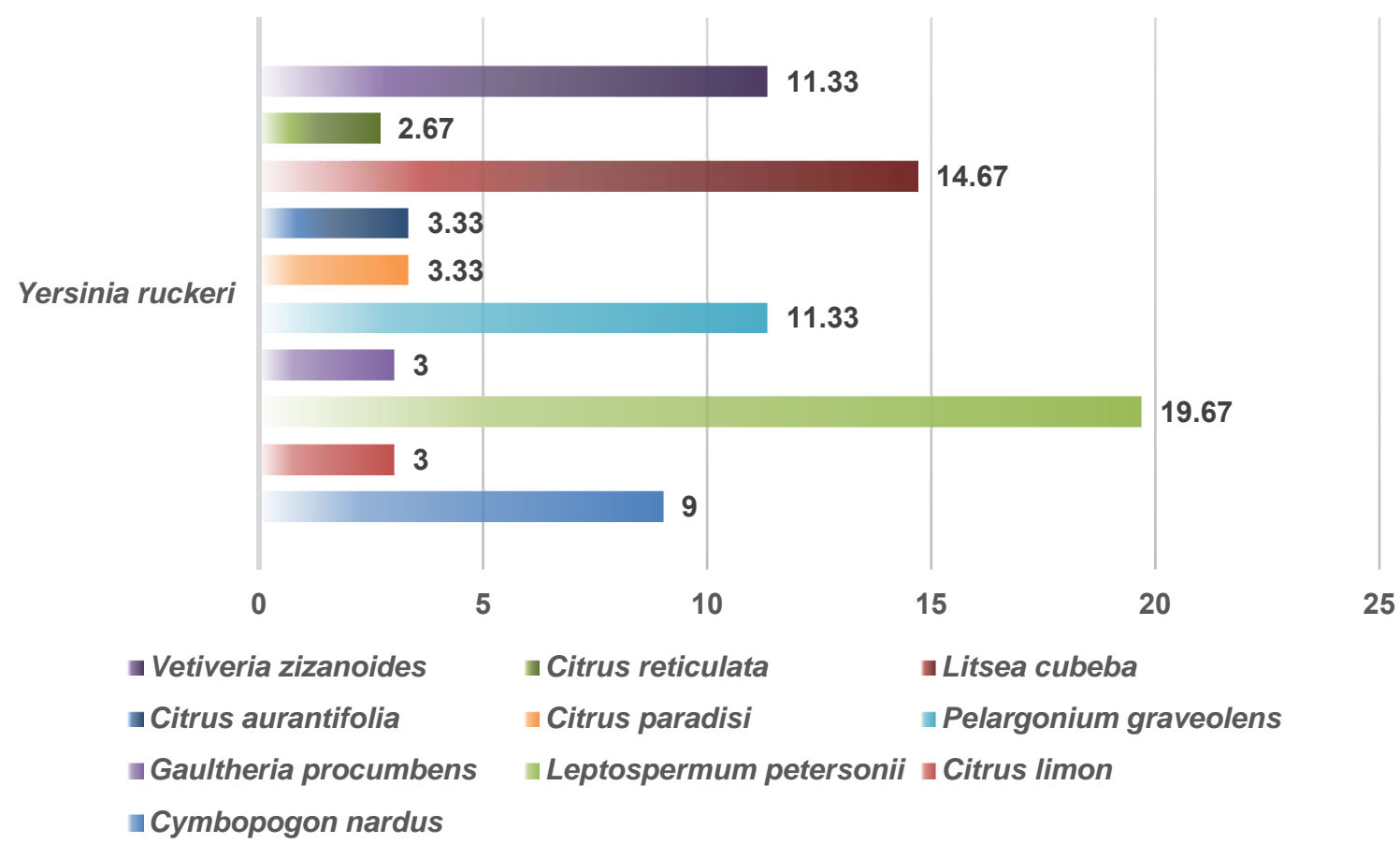

Figure 11. Antimicrobial activity of EOs against Yersinia ruckeri in $\mathrm{mm}$

Boukhatem et al. [17] investigated the antimicrobial effect of Pelargonium graveolens essential oil on various food spoilage microorganisms, including Rhodotorula glutinis, whose appropriate inhibition zone was $22.50 \mathrm{~mm}$ when disc was soaked in $10 \mu \mathrm{L}$ of Pelargonium graveolens essential oil. The antimicrobial effect became more significant when the concentration of essential oil increased: $20 \mu \mathrm{L}$ of essential oil per disc formed the mean inhibition zone of 27.17 $\mathrm{mm}$ and $30 \mu \mathrm{L}$ resulted in the mean inhibition zone of $29.83 \mathrm{~mm}$.

$\mathrm{Su}$ and $\mathrm{Ho}$ [18] tested the antimicrobial activity of Litsea cubeba essential oil on various microorganisms. All essential oils (except fruit essential oil) with concertation of $5 \mu \mathrm{L}$ per disc showed an inhibition zone against Bacillus cereus, Staphylococcus epidermis and Escherichia coli.

Adel et al. [19] focused on the antimicrobial activity of the skin of the rainbow trout (Oncorhynchus mykiss) after a diet supplemented with essential oil from peppermint. They found that Yersinia ruckeri had an inhibition zone at $1 \%$ of peppermint essential oil $8.9 \mathrm{~mm} \pm 0.8 \mathrm{~mm}$, at $2 \%$ it was $11.2 \mathrm{~mm} \pm 0.8 \mathrm{~mm}$ and at $3 \% 12.1 \mathrm{~mm}$ $\pm 1.1 \mathrm{~mm}$.

In general, Gram-positive bacteria were more sensitive to essential oils than to ticarcillin. Ticarcillin was more effective against Gramnegative bacteria than essential oils. Kačániová et al. [20] found that ticarcillin was one of the effective antimicrobials against Pseudomonas spp. in fish. In our study, ticarcillin was proven to be effective against Pseudomonas gessardii.

Chotikanatis et al. [21] tested Delftia acidovorans for various antibiotics and the bacteria was sensitive to ticarcillin. In our testing, we found that Delftia acidovorans was sensitive to ticarcillin, however, Leptospermum petersonii exhibited slightly stronger antimicrobial activity in comparison with ticarcillin.

Gogoi et al. [22] found that silica obtained from Litsea cubeba fruit has the best antimicrobial activity on $B$. cereus and $S$. aureus with inhibition zone of 7 and $11 \mathrm{~mm}$ at the same concentration of $500 \mu \mathrm{g} / \mathrm{mL}$.

Wang and Liu [23] showed that Litsea cubeba silica inhibited the growth of $B$. subtilis, E. coli, $E$. faecalis, $M$. albicans, $P$. aeruginosa, $S$. aureus with inhibition zone from 10.1 to $35.0 \mathrm{~mm}$.

Djenane [24] studied essential oils obtained from Algerian citrus (Citrus aurantium, Citrus sinestris and Citrus limon) on $S$. aureus, a common pathogen of Sardine pilchardus. He found that lemon essential oil with an inhibition zone diameter (including a $6 \mathrm{~mm}$ disc) of $30.33 \mathrm{~mm}$ had the best antimicrobial effects on $S$. aureus.

For the determination of antimicrobial activity by the method of minimum inhibitory concentration, the same essential oils as for the determination of antimicrobial activity were used. All tested essential oils showed antimicrobial activity on the 
selected microorganisms (Table 1). Against Aerococcus spp., Litsea cubeba EOs was the most effective at MICs concentrations of 50: 1.50 $\mu \mathrm{L} / \mathrm{mL}$ and MICs 90: $1.60 \mu \mathrm{L} / \mathrm{mL}$. Growth of Yersinia spp. inhibited Litsea cubeba at MICs of 50: $1.50 \mu \mathrm{L} / \mathrm{mL}$ and MICs 90: $1.60 \mu \mathrm{L} / \mathrm{mL}$. Against yeast Rhodotorula spp., Litsea cubeba was the most effective with a concentration of MICs 50: $1.70 \mu \mathrm{L} / \mathrm{mL}$ and MICs 90: $2.68 \mu \mathrm{L} / \mathrm{mL}$. Against the growth of Delftia acidovorans, Leptospermum petersonii was the best with MICs $50: 1.70 \mu \mathrm{L} / \mathrm{mL}$ and MICs 90: $2.68 \mu \mathrm{L} / \mathrm{mL}$. For Enterococcus faecium, had the best minimum inhibitory concentration was achieved with Leptospermum petersonii with MICs 50: $1.70 \mu \mathrm{L} / \mathrm{mL}$ and MICs 90 : $2.68 \mu \mathrm{L} / \mathrm{mL}$. Against Enterococcus moraviensis, Cymbopogon nardus had the best minimum inhibitory concentration of with MICs 50: 1.70 $\mu \mathrm{L} / \mathrm{mL}$ and MICs 90: $2.68 \mu \mathrm{L} / \mathrm{mL}$ Against Yersinia ruckeri Leptospermum petersonii was highly effective with a concentration of MICs 50: 1.70 $\mu \mathrm{L} / \mathrm{mL}$ and MICs 90: $2.68 \mu \mathrm{L} / \mathrm{mL}$. Litsea cubeba silica with MICs 50: $1.70 \mu \mathrm{L} / \mathrm{mL}$ and MICs 90: 2.68 $\mu \mathrm{L} / \mathrm{mL}$ was most effective for the growth of Aerococcus viridans.

Antimicrobial activity of essential oils with microdilution method in $\mu \mathrm{L} / \mathrm{mL}$

Table 1.

\section{Tested \\ microorganisms}

Essential oil

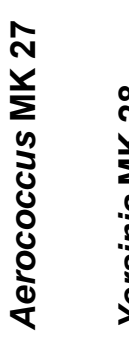

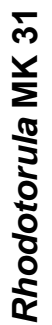
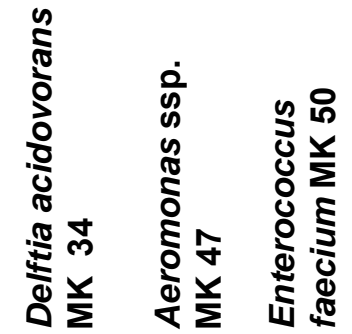

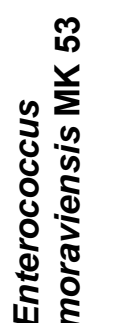

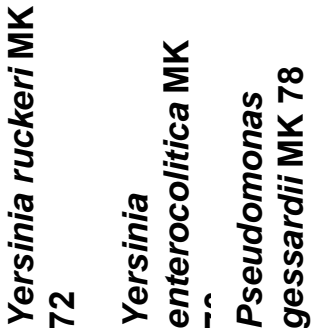

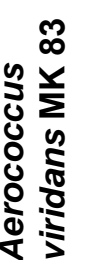

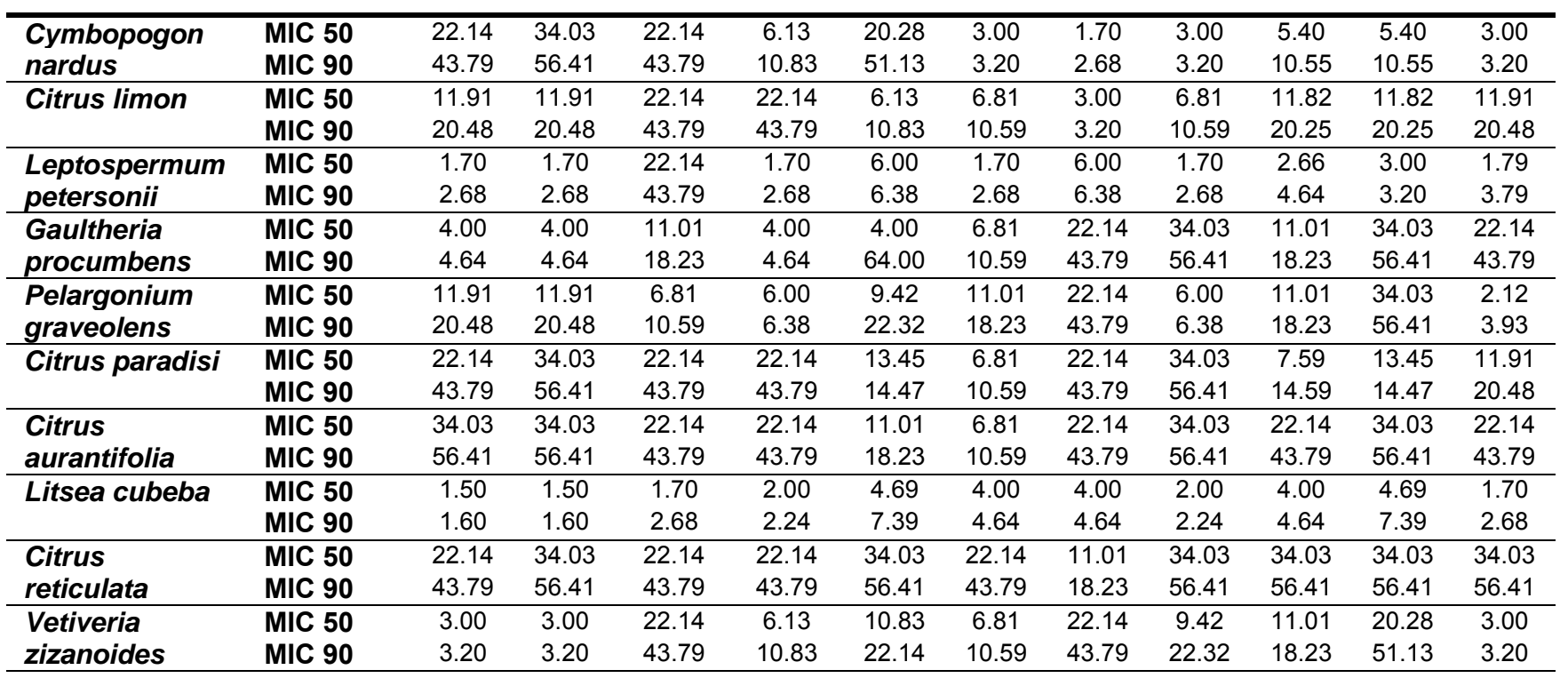

Singh et al. [25] in a study of the antimicrobial activity of Cymbopogon nardus essential oil found that it inhibited the growth of 36 species of aqueous pathogens with MICs from $0.24 \mu \mathrm{g} / \mathrm{mL}$ for Pseudomonas and Salmonella to $0.97 \mu \mathrm{g} / \mathrm{mL}$ for Edwardsiella and Aeromonas strains. Cymbopogon nardus has been shown to be effective against $S$. aureus, Bacillus subtilis, Proteus vulgaris and Pseudomonas aeruginosa. Despite of testing of another Pseudomonas species - Pseudomonas gessardii, also in our case Cymbopogon nardus was very effective against the bacteria.

Nguyen et al. [26] studied the antimicrobial activity of Litsea cubeba essential oil on Aeromonas hydrophila isolated from Caprinus caprio. They found that essential oil (with linalool content of 95\%) had bactericidal effects against Aeromonas hydrophila with MIC of $0.96 \mu \mathrm{g} / \mathrm{mL}$. The study concluded that adding Litsea cubeba (with an increased linalool content) to the diet in an amount of $4-8 \%$ would reduce the use of antimicrobials to treat diseases caused by 
Aeromonas hydrophila and increase the immunity of Cyprinus carpio.

Wei and Wee [27] discussed the antimicrobial activity of Cymbopogon nardus essential oil on bacteria isolated from the internal organs of aquatic animals (Aeromonas spp., Pseudomonas spp., Aeromonas hydrophila, Yersinia enterocolitica, and other microorganisms). In Aeromonas spp., described MICs were from 0.488 $\mu \mathrm{g} / \mathrm{mL}$ to $0.977 \mu \mathrm{g} / \mathrm{mL}$, for Pseudomonas spp. MICs $0.244 \mu \mathrm{g} / \mathrm{mL}$, Aeromonas hydrophila and Yersinia enterocolitica - MICs $0.488 \mu \mathrm{g} / \mathrm{mL}$.

Adel et al. [19] investigated the MIC of peppermint essential oil on mucus of Rainbow trout containing, among other bacteria, Yersinia ruckeri. At a concentration of $1 \%$ essential oil in the diet, the MICs of Yersinia ruckeri was $125 \mu \mathrm{g} / \mathrm{mL}$, at $2 \%$ the MICs was $100 \mu \mathrm{g} / \mathrm{mL}$ and at $3 \%$ the MICs was $75 \mu \mathrm{g} / \mathrm{mL}$.

\section{Conclusions}

The antimicrobial activity of plant extracts was determined by the disc diffusion method. Comparing the values found and evaluating the results, it could be concluded that the largest inhibition zone was reached by Leptospermum petersonii. Citrus paradise essential oil showed the smallest zone of inhibition. When tested for antimicrobial activity by the minimum inhibitory concentration method, the essential oils showed activity against all microorganisms. The most effective was Litsea cubeba and followed by essential oil of Leptospermum petersonii. $L$. petersonii in our study showed correlation between disc diffusion method and minimum inhibitory concentration in the inhibitory effect against tested microorganisms.

\section{Acknowledgements}

This work has been supported by the grant APVV SK-BY-RD-19-0014 "The formulation of novel compositions and properties study of the olysaccharides based edible films and coatings with antimicrobial and antioxidant plant additives."

\section{References}

1. Bakkali, F., Averbeck, S., Averbeck, D., \& Idaomar, M. (2008). Biological effects of essential oils A review. Food and Chemical Toxicology, 46(2), 446475. https://doi.org/10.1016/j.fct.2007.09.106

2. Tongnuanchan, P., \& Benjakul, S. (2014). Essential Oils: Extraction, Bioactivities, and Their Uses for Food Preservation. Journal of Food Science, 79(7), 12311249. DOI: $10.1111 / 1750-3841.12492$

3. Wany, A., Jha, S., Nigam, V. K., \& Pandey, D. M. (2013). Chemical analysis and therapeutic uses of citronella oil from Cymbopogon winterianus: A short review. International Journal of Advanced Research, 1(6), 504-521.
4. Wany, A., Kumar, A., Nallapeta, S., Jha, S., Nigam, V. K., \& Pandey, D. M. (2014). Extraction and characterization of essential oil components based on geraniol and citronellol from Java citronella (Cymbopogon winterianus Jowitt). Plant Growth Regulation, 73(2), 133-145.

5. Nguyen, H., Campi, E. M., Jackson, W. R., \& Patti, A. F. (2009). Effect of oxidative deterioration on flavour and aroma components of lemon oil. Food Chemistry, 112(2), 388-393. https://doi.org/10.1016/j.foodchem.2008.05.090

6. Carson, C. F., Hammer, K. A., \& Riley, T. V. (2006). Melaleuca alternifolia (Tea Tree) Oil: a Review of Antimicrobial and Other Medicinal Properties. Clinical Microbiology Reviews, 19(1), 50-62. doi: 10.1128/CMR.19.1.50-62.2006

7. Salleh, F., Anuar, T. S., Yasin, A. M., \& Moktar, N. (2012). Wintergreen oil: A novel method in Wheatley's trichrome staining technique. Journal of Microbiological Methods, 91(1), 174-178. DOI: 10.1016/i.mimet.2012.08.004

8. Sharopov, F. S., Zhang, H., \& Setzer, W. N. (2014). Composition of geranium (Pelargonium graveolens) essential oil from Tajikistan. American Journal of Essential Oils and Natural Products, 2(2), 13-18.

9. Ng, T. B., Bekhit, A. E. A., Fang, E. F.,Li, X., Lu, Q., Guo, H., \& Wong, J. H. (2014). Chapter 52-Grapefruit (Citrus paradisii) Oils. In PREEDY, Victor R. Essential Oils in Food Preservation, Flavor and Safety. London: Academic Press.

10.Deng, W., Liu, K., Cao, S., Sun, J., Zhong, B., \& Chun, J. (2020). Chemical Composition, Antimicrobial, Antioxidant, and Antiproliferative Properties of Grapefruit Essential Oil Prepared by Molecular Distillation. Molecules, 25(1), 217. DOI: $10.3390 /$ molecules 25010217

11. Cruz-Velenzuela, M. R., Tapia-Rodríguez, M. R., Vazquez-Armenta, F. J., Silvia-Espinoza, B. A., \& Ayala-Zavala, J. F. (2016). Chapter 61 - Lime (Citrus aurantifolia) oils. In PREEDY, Victor R. Essential Oils in Food Preservation, Flavor and Safety. London: Academic Press.

12. Chen, Y., Wang, Y., Han, X., Si, L., Wu, Q., \& Lin, L. (2013). Biology and Chemistry of Litsea cubeba, a promising industrial tree in China. Journal of Essential Oil Research, 25(2), 103-111. https://doi.org/10.1080/10412905.2012.751559

13. Dugo, G., \& Giacomo, A. D. (2002). Citrus: The genus Citrus. 1st. pub. s.I. : CRC Press.

14. Sinha, S., Jothiramajayam, M., Ghosh, M., Jana, A., Chatterji, U., \& Mukherjee, A. (2015). Vetiver oil (Java) attenuates cisplatin-induced oxidative stress, nephrotoxicity and myelosuppresion in Swiss albino mice. Food and Chemical Toxicology, 81, 120-128. DOI: 10.1016/j.fct.2015.04.018

15. Rodricks, E.G. (1991). Indegenous Pathogen: Vibrionaceae of Microbiology of Marine Food Products. Reinhold, New York.

16. Kačániová, M., Galovičová, L., Ivanišová, E., Vukovic, N. L., Štefániková, J., Valková, V., Borotová, P., Žiarovská, J., Terentjeva, M., Felšöciová, S., \& Tvrdá, E. (2020). Antioxidant, Antimicrobial and Antibiofilm Activity of Coriander (Coriandrum sativum L.) Essential Oil for Its Application 
in

Foods. Foods, 9 ,

282. https://doi.org/10.3390/foods9030282

17. Boukhatem, M. N., Kameli, A., \& Saidi, F. (2013). Essential oil of Algerian rose-scented geranium (Pelargonium graveolens): Chemical composition and antimicrobial activity against food spoilage pathogens. Food Control, 34(1), 208-213. https://doi.org/10.1016/j.foodcont.2013.03.045

18. Su, Y. Ch., \& Ho, Ch. L., (2016). Essential oil Compositions and Antimicrobial Activities of Various Parts of Litsea cubeba from Taiwan. Natural Product Communications, 11(4), 515-518.

19. Adel, M., Pourgholam, R., Zorriehzahra, J., \& Ghiasi, M. (2016). Hemato - Immunological and biochemical parameters, skin antibacterial activity, and survival in rainbow trout (Oncorhynchus mykiss) following the diet supplemented with Mentha piperita against Yersinia ruckeri. Fish and Shellfish Immunology, 55, 267-273. DOI: $10.1016 /$ i.fsi.2016.05.040

20. Kačániová, M., Terentjeva, M., Vukovic, N., Puchalski, C., Roychoudhury, S., Kunová, S., Klūga, A., Tokár, M., Kluz, M., \& Ivanišová, E. (2017). The antioxidant and antimicrobial activity of essential oils against Pseudomonas spp. isolated from fish. Saudi Pharmaceutical Journal, 25(8), 1108-1116. DOI: 10.1016/j.jsps.2017.07.005

21. Chotikanatis, K., Bäcker, M., Rosas-Garcia, G., \& Hammerschlag, M. R. (2011). Recurrent IntravascularCatheter-Related Bacteremia Caused by Delftia acidovorans in a Hemodialysis Patient. Journal of Clinical Microbiology, 49(9), 3418-3421. DOI: $10.1128 / \mathrm{JCM} .00625-11$
22. Gogoi, R., Loying, R., Sarma, N., Munda, S., Pandey, S. K., \& Lal, M. (2018). A comparative study on antioxidant, anti-inflammatory, genotoxicity, antimicrobial activities and chemical composition of fruit and leaf essential oils of Litsea cubeba Pers. from North-east India. Industrial Crops and Products, 125, 131-139. https://doi.org/10.1016/j.indcrop.2018.08.052 23. Wang, H., \& Liu, Y. (2010). Chemical Composition and Antibacterial Activity of Essential Oils from Different Parts of Litsea cubeba. Chemistry and Biodiversity, 7(1), 229-235. DOI: 10.1002/cbdv.200800349

24. Djenane, D. (2015). Chemical Profile, Antibacterial and Antioxidant Activity of Algerian Citrus Essential Oils and Their Appication in Sardina pilchardus. Foods, 4(2), 208-228. DOI: $10.3390 /$ foods4020208

25. Singh, B. R., Agrawa, R., Vadhan, P., Bhardwa, M., \& Dubey, S. (2015). Antimicrobial Activity of Citronella Essential Oil on Antimicrobial Drug Resistant Bacteria from Veterinary Clinical Cases. Clinical and Medical Biochemistry, 1(1), 1-9. DOI: 10.4172/24712663.1000106

26. Nguyen, H. V., Caruso, D., Nguyen, N. T., Trinh , T. T., Meile, J-T., Chu-Ky, S., \& Sarter, S. (2016). Antibacterial activity of Litsea cubeba (Lauraceae, May Chang) and its effects on the biological response of common carp Cyprinus carpio challenged with Aeromonas hydrophila. Journal of Applied Microbiology, 121(2), 341-351. DOI: 10.1111/jam.13160

27. Wei, L. S., \& Wee, W. (2013). Chemical composition and antimicrobial activity of Cymbopogon nardus citronella essential oil against systemic bacteria of aquatic animals. Iranian Journal of Mlcrobiology, 5(2), 147-152. 